\title{
New French government line-up looks promising for research
}

\section{Paris}

THE re-election of François Mitterand as President of France, followed by the nomination of a new government, has brought several familiar socialists back to key ministries. On paper the changes look good for research and higher education, but the academic community is keeping its champagne on ice. It is still uncertain

\section{IMAGE \\ UNAVAILABLE FOR COPYRIGHT REASONS}

\section{Hubert Curien, again minister for research.}

exactly how Mitterrand will translate his pro-research campaign promises into action (see Nature 332, 768; 1988). But few expect an immediate return to the expansive optimism of the socialists' last mandate during the early $1980 \mathrm{~s}$.

As widely expected, Mitterrand chose Michel Rocard as Prime Minister. Rocard, whose father, Yves Rocard, was director of the Physics Laboratory at the École Normale Supérieure, was minister of agriculture in the Fabius government from 1983 until he resigned in 1985, having disapproved of proposed electoral reforms. Rocard took only two days to name his government. Instead of the promised 'centrist' cabinet, with an attentive ear tuned to the right-wing majority, the lineup has already been branded 'mitterandist' and may turn out to be unworkable without a shift in the balance of power.

Mitterrand's faith in education and research as a long-term investment is clearly translated in the new government. Highflyer Lionel Jospin, who has just resigned as head of the socialist party, has been given one of the four ministries of state education, research and sports. But, in practice, it will be Hubert Curien, who replaces Jacques Valade as minister delegate for research, who will be at the sharp end of government policy.

Curien was minister for research and technology in the Fabius government until March 1986, when the socialists lost power, and so is well-known to the academic community. A physicist specializing in crystallography, Curien lectured at the University of Paris VI for several years. He later became director of the Centre National de la Recherche Scientifique. Between 1976 and 1984 he was president of the National Space Research Centre and, from 1981 to 1984, president of the European Space Agency.

Curien's experience of the domestic and European space programmes will, however, have little direct outlet in his new post, as responsibility for space research has been taken away from the research ministry and given to the ministry for posts and telecommunications, now headed by former socialist defence minister Paul Quilès. But Curien is likely to have his hands full. In 1986, just before the socialists lost power, Curien proudly boasted of the creation of 1,400 new research posts and a 14 per cent increase in the state research budget. Much of this effort was undone when, in 1986 and 1987, the Chirac government shifted the emphasis away from direct state spending on research, towards policies to encourage private sector participation.

Ironically, it was Curien who advanced the use of tax incentives to encourage private sector spending on research and, like his right-wing successors, felt that too few scientists were entering industry. This bipolar attitude to research spending makes it difficult to judge how, with Jospin, he will interpret the president's commitment to science and technology.

At the headquarters of the leading union for academics and science researchers, SNCS-FEN, Curien's appointment has provoked only cautious optimism. "We had Curien as minister for two years", says biochemist Paul Janiaud, the union's secretary, "so we know him. He had some very firm ideas. We hope he will be more open to dialogue than he was the last time." What researchers wish for from Curien is a return to the previous socialist policy of a net annual progression in recruitment of young postdocs - to offset ageing of the scientific community.

Having seen how the French voted during the presidential elections Mitterrand has promised "openness" (toward the political centre) in his government. But it also became clear during the electoral campaign that 'cohabitation' with the right-wing majority was no longer possible. Mitterrand has now chosen to dissolve the assembly, calling for a general election in the hope of gaining a more comfortable majority.

\section{London Zoo to get $£ 10$ million from DoE for new twenty-first century image}

\section{London}

THE brand of free marketeering zealously advocated by the present British government has caught up with London Zoo the world's oldest zoological garden. A cash injection of $£ 10$ million together with a stiff dose of hard-headed commercial management should rejuvenate the ailing zoo for a financially independent future, says the government. The 162-year-old Zoological Society of London, which runs the zoo and its sister establishment, Whipsnade Park, appears to agree.

Since 1984, when the government stepped in to rescue the zoo from the brink of bankruptcy, the society has depended on an annual grant of $£ 2$ million from the Department of the Environment (DoE).

Last week the DoE announced that it is to cease its annual subsidy and will instead give the society a final single payment of $£ 10$ million for 'modernization'. As part of the deal, the society's research organization, the Institute of Zoology, will become formally attached to the University of London and will receive an annual grant of $£ 1.3$ million through the Universities Funding Council, which under government proposals will next year replace the existing University Grants Committee.

For the institute, which was created in 1977 through the amalgamation of the Wellcome Institute of Comparative Physi- ology and the Nuffield Institute of Comparative Medicine, this is good news. Income will no longer be largely dependent on such capricious factors at attendance figures at the zoo.

Although the possibility of handing over responsibility for the institute to one of the research councils was considered, it was decided that because the institute has dealings with all four principal research councils, a biased research programme might have resulted if core funding was received from one council only. Additionally, strong informal links already exist between the institute and the university.

For the zoo, the plan is to delegate full management functions to a wholly owned subsidiary company, to be called Zoo Operations Limited and whose chief executive will be Mr Andy Grant, who has previously been involved with San Diego and Philadelphia zoos in the United States. The new company's first job will be to produce an operational plan, which will need to be ratified by the government as part of the conditions for the endowment.

The zoo's administrators say it is too early to go into details of a precise strategy for 'revenue enhancement', but that any changes will be subject to the zoo's charter, and fears that the zoo will become a version of 'Disneyland' are unfounded.

Simon Hadlington 